\title{
SIADH in the context of localised Herpes-Zoster infection
}

\author{
Catarina Cidade-Rodrigues ${ }^{\circledR 1}$, Adriana Silva ${ }^{\circledR 2}{ }^{2}$, Fátima Costa ${ }^{\circledR 3}$, Catarina Couto ${ }^{3}$, Filipe Esteves ${ }^{4}$, \\ Ana João Sá ${ }^{5}$, Inês Ferreira ${ }^{3}$
}

${ }^{1}$ Endocrinology Department, Centro Hospitalar do Tâmega e Sousa, Penafiel, Portugal

${ }^{2}$ Intensive Medicine Department, Centro Hospitalar do Tâmega e Sousa, Penafiel, Portugal

${ }^{3}$ Internal Medicine Department, Centro Hospitalar do Tâmega e Sousa, Penafiel, Portugal

${ }^{4}$ Ophtalmology Department, Centro Hospitalar do Tâmega e Sousa, Penafiel, Portugal

Key words: inappropriate ADH syndrome; herpes zoster; Bell's palsy; hyponatraemia

Although the association between the syndrome of inappropriate antidiuretic hormone secretion (SIADH) and localised herpes-zoster infection is rare, it can cause prolonged hyponatraemia with significant morbidity and mortality, especially in the elderly.

We report a case of an 87-year-old Caucasian male who presented in the emergency department (ED) with a 12-day history of a painful skin rash in the right frontoparietal region. He had previously been to the hospital's ED complaining of conjunctival erythema and was diagnosed with herpes-zoster ophthalmicus (HZO) and treated with oral valaciclovir. After 6 days, he returned because he had developed right facial paralysis. He had no fever, nausea, vomiting, diarrhoea, polydipsia, headaches, or seizures.

The physical examination revealed a skin rash with multiple vesicular and crusted lesions in the right ophthalmic region (V1) of the trigeminal nerve, painful to palpation. He had right peripheral facial paralysis, with a positive Hutchinson sign. There were no vesicles in the external auditory canal or other cutaneous rashes. He had no meningeal signs. His blood pressure was $178 / 90 \mathrm{mmHg}$, heart rate 68 beats/min, body temperature $36.5^{\circ} \mathrm{C}$, there were no significant findings in cardiopulmonary auscultation, no dehydration signs, and no systemic signs of congestion.

Past medical history included hypertension, type 2 diabetes mellitus, dyslipidaemia, ischaemic heart disease, permanent atrial fibrillation, and peripheral vascular disease. He was taking furosemide $(40 \mathrm{mg}$ q.d.), carvedilol (6.25 mg q.d.), trimetazidine (35 mg q.d.), ivabradine (7.5 mg q.d.), lisinopril (20 mg q.d.), rivaroxaban (15 mg q.d.), metformin (1 g q.d.), simvastatin (20 mg q.d.), and clonazepam (2 mg q.d.). No recent dosage changes had been made and no new drugs had been started recently. He denied smoking and alcohol consumption.

The patient was diagnosed with $\mathrm{HZO}$ infection associated with Bell's palsy and was admitted in the Internal Medicine department.

His laboratory results at admission (Tab. 1) showed a hypotonic hyponatraemia $(127 \mathrm{mmol} / \mathrm{L})$, high urine osmolality, urinary sodium concentration above $30 \mathrm{mmol} / \mathrm{L}$, normoglycaemia, normal renal and thyroid functions, absence of cortisol deficiency, and uric acid below $4 \mathrm{mg} / \mathrm{dL}$ [1]. His chest X-ray showed no evidence of new consolidations or pulmonary masses. We then concluded the diagnosis of SIADH secondary to the viral infection. The concomitant resolution of the hyponatraemia and the vesicular lesions supported this diagnosis and suggested a link between these two conditions.

In this patient, other possible causes for hyponatraemia were the treatment with furosemide and/or lisinopril. However, these drugs had not been introduced recently nor its regular dosage altered, and a normal serum sodium value had been documented months prior to this episode.

He was treated with fluid restriction $(750 \mathrm{~mL} /$ day $)$ and $\mathrm{NaCl} 0.9 \% 1000 \mathrm{~mL} / 24 \mathrm{~h}$ for four days, resulting in a progressive increase in sodium levels (Fig. 1). He completed 7 days of intravenous acyclovir, 8 days of oral corticosteroid therapy, topical eye treatment, and started facial muscle rehabilitation. All his vesicular lesions evolved into the crust phase and some facial muscle strength was regained. 
Table 1. Laboratory results at admission in the presented case

\begin{tabular}{|c|c|c|}
\hline $\begin{array}{l}\text { Laboratory parameters } \\
\text { at admission }\end{array}$ & Value & $\begin{array}{c}\text { Reference } \\
\text { range }\end{array}$ \\
\hline \multicolumn{3}{|l|}{ Serum } \\
\hline Haemoglobin $[\mathrm{g} / \mathrm{dL}]$ & 12.8 & $13.9-16.3$ \\
\hline C-reactive protein [mg/dL] & 5.0 & $<5.0$ \\
\hline Urea [mg/dL] & 18 & $10-50$ \\
\hline Creatinine $[\mathrm{mg} / \mathrm{dL}]$ & 0.58 & $0.81-1.44$ \\
\hline Sodium $\left(\mathrm{Na}^{+}\right)[\mathrm{mmol} / \mathrm{L}]$ & 127 & $135-145$ \\
\hline Potassium $\left(\mathrm{K}^{+}\right)[\mathrm{mmol} / \mathrm{L}]$ & 3.7 & $3.5-5.0$ \\
\hline Chlorine $\left(\mathrm{Cl}^{-}\right)[\mathrm{mmol} / \mathrm{L}]$ & 89 & 101-109 \\
\hline Serum osmolality [m0sm $/ \mathrm{kg}]$ & 266.9 & $275-285$ \\
\hline Glucose [mg/dL] & 99 & $76-110$ \\
\hline AST [U/L] & 46 & $10-37$ \\
\hline ALT [U/L] & 42 & $10-37$ \\
\hline Total cholesterol [mg/dL] & 140 & $<200$ \\
\hline HDL-cholesterol [mg/dL] & 52 & $>40$ \\
\hline LDL-cholesterol [mg/dL] & 77 & $<130$ \\
\hline Triglycerides [mg/dL] & 56 & $<150$ \\
\hline Uric acid [mg/dL] & 3.6 & $3.5-7.2$ \\
\hline $\mathrm{HbA}_{1 \mathrm{C}}(\%)$ & $6.0 \%$ & $<6.0$ \\
\hline TSH [uUl/mL] & 0.49 & $0.38-5.33$ \\
\hline Free T4 [ng/dL] & 0.99 & $0.54-1.24$ \\
\hline Morning cortisol [ug/dL] & 28.10 & $6.7-22.6$ \\
\hline ACTH $[\mathrm{pg} / \mathrm{mL}]$ & 25.7 & $9-52$ \\
\hline Antibodies HIV 1/2 & Non reactive & \\
\hline \multicolumn{3}{|l|}{ Urine } \\
\hline Sodium $\left(\mathrm{Na}^{+}\right)[\mathrm{mmol} / \mathrm{L}]$ & 67.99 & \\
\hline Potassium $\left(\mathrm{K}^{+}\right)[\mathrm{mmol} / \mathrm{L}]$ & 10.99 & \\
\hline Urine osmolality [m0sm/kg] & 259 & $300-900$ \\
\hline
\end{tabular}

AST — aspartate transaminase; ALT — alanine transaminase; $\mathrm{HbA}_{1 \mathrm{c}}$ - glycated haemoglobin; TSH — thyroid-stimulating hormone; ACTH — adrenocorticotropic hormone; HIV — human immunodeficiency virus

At day 4 after admission, he developed hypokalaemia $(\mathrm{K}+3.3 \mathrm{mmol} / \mathrm{L})$, probably secondary to acyclovir, which was corrected with potassium chloride $(\mathrm{KCl})$ administration orally for 5 days and intravenously for 2 days. Other complications that developed in this patient were right eye herpetic keratitis and a corneal ulcer.

After 10 days, he was discharged with a serum sodium concentration of $136 \mathrm{mmol} / \mathrm{L}$ and serum potassium concentration of $3.6 \mathrm{mmol} / \mathrm{L}$. Regular follow-up was made later in the outpatient clinic of Ophthalmology and Internal Medicine.

In total, 16 cases of SIADH secondary to localised Herpes-Zoster were published to date, this case being

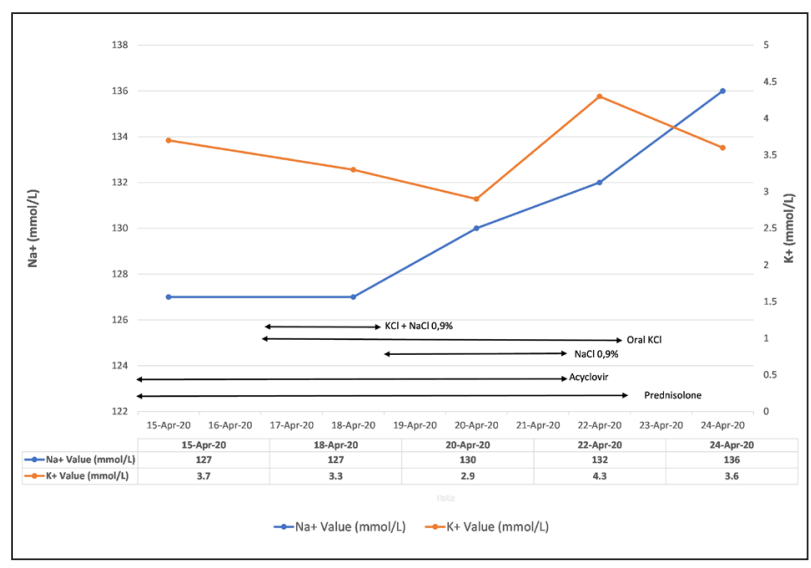

Figure 1. Serum sodium $(\mathrm{Na}+)$ and potassium $(\mathrm{K}+)$ values, in $\mathrm{mmol} / \mathrm{L}$, measured at the patient's admission and course of treatment, discriminated by days

the $17^{\text {th }}$ ever described. It is the first one associated with Bell's palsy and the second one complicated by hypokalaemia [2]. About $41 \%$ of reported cases presented as HZO. Considering that $10-20 \%$ of all herpes-zoster infections develop $\mathrm{HZO}$, we propose a higher tendency to develop secondary SIADH in HZO.

The most accepted pathophysiological mechanisms explaining this association are that the VZV interferes with the regulation of ADH secretory pathway [3], through viral dissemination to the hypothalamic nuclei and direct transmission of osmoreceptor signals [4]. Pain can also be a potent non-osmotic stimulus for ADH secretion [1].

SIADH secondary to localised herpes-zoster infection is uncommon, and the presented case supports the hypothesis of a correlation between these two conditions. It is unique because it is the first ever associated with Bell's palsy.

\section{Conflicts of interest}

The authors declare that there are no competing interests.

\section{References}

1. Spasovski G, Vanholder R, Allolio B, et al. Clinical practice guideline on diagnosis and treatment of hyponatraemia. Eur J Endocrinol. 2014; 171(1): X1, doi: 10.1530/eje-13-1020e, indexed in Pubmed: 24562549.

2. Bassi V, Fattoruso O, Santinelli C. Localized herpes zoster infection: a rare cause of syndrome of inappropriate secretion of antidiuretic hormone. Oxf Med Case Reports. 2017; 2017(11): omx065, doi: 10.1093/omcr/omx065, indexed in Pubmed: 29230301.

3. Kucukardali Y. Herpes zoster ophthalmicus and syndrome of inappropriate antidiuretic hormone secretion. Intern Med. 2008; 47(5): 463-465, doi: 10.2169/internalmedicine.47.0629, indexed in Pubmed: 18310984.

4. Wang CC, Shiang JC, Chen JT, et al. Syndrome of inappropriate secretion of antidiuretic hormone associated with localized herpes zoster ophthalmicus. J Gen Intern Med. 2011; 26(2): 216-220, doi: 10.1007/s11606-010-1517-4, indexed in Pubmed: 20878495. 